Bolm Inst. oceanogr., S Paulo, 34 (ünico):55-69, 1986

\title{
EARLY DEVELOPMENT OF Thyrsitops lepidopoides (PISCES: GEMPYLIDAE)
}

Gosuke SATO ${ }^{1}$ \& Yasunobu MATSUURA ${ }^{2}$

1 Empresa Catarinense de Pesquisa Agropecuária S.A. (EMPASC), Estação Experimental de Itajaí, (Caixa Postal 277, 88300 Itajaí, SC)

2 Instituto Oceanográfico da Universidade de São Paulo, (Caixa Postal 9075, 01051 São Paulo, SP)

\section{Synopsis}

Thyrsitops lepidopoides larvae were caught with Bongo nets in the upper $200 \mathrm{~m}$ of the ocean from the coast of southern Brazil during 1975-1978. Based on a serie of 271 specimens ranging from 2.5 to $24.0 \mathrm{~mm}$ body lenght, morphological and osteological development of the larvae and juveniles is described. Small larvae (2.5-12.0 mm NL) can be distinguished from all known gempylid larvae by the presence of a distinct melanophore at the base of the dorsal and anal fins. The larvae have well developed dorsal and ventral spines. It is the only gempylid with six preopercular spines and non-serrated dorsal and ventral spines during the larval stage.

Descriptors: Fish larvae, Larval development, Animal morphology, Osteology, Morphogenesis, Thyrsitops lepidopoides, Gempylidae, Southern Brazilian coast.

Descritores: Larvas de peixes, Desenvolvimento larval, Morfologia animal, Osteologia, Morfogenia, Thyrsitops lepidopoides, Gempylidae, Costa sul: Brazil.

\section{Introduction}

The larval morphology of gempylid fishes has been described by many authors (Voss, 1954; Jager, 1955; Jones, 1960;

Strasburg, 1964; Yevseyenko \& Serebryakov, 1974; Nakamura \& Paxton, 1977; Nishikawa \& Nakamura, 1978; Gorbunova, 1977, 1982; Nishikawa, 1982, $1984 a, b, c)$. Collette et al. (1984) treated the larval morphology and phyletic relationships of all gempylids, but still our knowledge of the early life history of gempylids is incomplete.

Nishikawa (1984a) recently described T. lepidopoides larvae based on only five specimens (one of them partially damaged and deformed), but his description is precarious. We feel that it is necessary to give a more detailed description of this species.

In this paper we describe morphological and osteological development of $T$. lepidopoides based on 271 specimens collected in the south Brazilian waters .

Publ. n. 617 do Inst. oceanogr. da Usp.

\section{Material and methods}

Larvae used in this study were collected during seven survey cruises conducted off the southern Brazilian coast from 1975 to 1978 . The plankton samples were collected with Bongo nets and preserved in $10 \%$ formalin. After sorting, fish eggs and larvae were identified to family group or lower taxon. From the larval specimens identified as Gempylidae, Thyrsitops lepidopoides larvae were separated following the sequencial developmental stages. We divided the larval period into three stages, preflexion, flexion and postflexion, based on the flexion of nothochord which occurs during caudal fin formation (Moser \& Ah1strom, 1970). The larvae were measured with a movable micrometer attached to a stereoscopic dissecting microscope. Measurements were made as follows: Notochord length (NL); from anterior tip of snout to posterior tip of notochord for preflexion and flexion larvae. Standard length (SL); from anterior tip of snout to posterior end of hypural plate for the postflexion larvae. 
For our osteological study, Iarvae were cleared and stained with alcian blue and alizarin red following the double staining technique of Dingerkus \& Uhler (1977). All specimens studied for fin ray and bone development were maintained in $100 \%$ glycerin and studied under $25 \mathrm{X}$ and 50X magnification. Illustrations were made using a camera lucida. For cleared and stained specimens, colorless and alcian blue stained structures are shown in white and alizarin red stained structures are stippled. The cartilaginous structures were considered to be ossifying if they were stained with alzarin red.

Osteological terms and abbreviations used in this study follow those used by Potthoff et al. (1980).

\section{Results}

\section{Morphology}

Larvae are unique in the family Gempylidae in having no serrated dorsal and ventral fin spines. In other respects they show the typical gempylid larval form, such as a well-developed dorsal and ventral fin spines, conspicuous head spination, and base of spinous dorsal fin longer than soft dorsal fin base.

Preflexion stage larvae have aslender and 1aterally compressed body (Fig. 1A, $B, C)$. The notochord flexion of this species starts at $7.0 \mathrm{~mm}$ and ends at $12.0 \mathrm{~mm}$, thus the specimens smaller than $7.0 \mathrm{~mm}$ are preflexion larvae, those between 7.0 and $12.0 \mathrm{~mm}$ are flexion larvae and those larger than $12.0 \mathrm{~mm}$ are postflexion larvae.

F1exion larvae have a robust body form due to an increase in body depth and enlargement of the gut (Fig. 1D, E, F, G). By the end of the flexion stage, all fin counts are as in adult. During postflexion stage, larvae reaquire a slender, elongated body form as a result of rapid growth in length (Fig. $1 \mathrm{H}, \mathrm{I}, \mathrm{J})$.

Pigmentation is uniquely characterized by the presence of two melanophores at $2.5 \mathrm{~mm}$ NL: one on the base of dorsal fin at about 13-14 th myomere and another on the base of anal fin at about 21-24th myomere. These melanophores remain at the same position throughout early development up to $12.0 \mathrm{~mm} \mathrm{NL}$ and are not seen in any other known gempylid larva.
Besides the two melanophores mentioned above, preflexion làrvae have several melanophores over the midbrain which posteriorly spreading over the forebrain. Another patch of pigment is present over the dorsal part of gut. Pigment on the dorsal fin membrane firstly appears between the first and second dorsal spines at $6.2 \mathrm{~mm}$ NL (Fig. 1C) and later between the second and third dorsal spines at $7.5 \mathrm{~mm}$ NL (Fig. 1D). At this size the gut pigment spreads over the dorso-lateral region. Flexion larvae have similar pigment patterns, but some melanophores appear on the preopercle. Three pigment spots occur on the posterior portion of the upper $\mathrm{j}$ aw at $10.7 \mathrm{~mm} \mathrm{NL}$ (Fig. 1G).

In postflexion stage, two melanophores observed on the bases of dorsal and anal fins at early stages are now obscured medially by a row of melanophores which develop along the dorsal and anal fin bases. Melanophores over the head and gut regions increase in number with growth.

\section{Osteology}

\section{Preopercular spination}

The first preopercular spine appear at $4.5 \mathrm{~mm} \mathrm{NL}$, on the posterior edge. Following this, several spines appear on the preopercle and at the late preflexion stage, these spines become five principal spines and three spinules on the preopercular crest (Fig. 2A, B). During the flexion stage, the preopercular spines attain it's maximum number (=six) (Fig. 2C, D, E). Counting dorsal to ventral, the fourth spine positioned at the angle of preopercle, is the longest one. No serrations occur on the preopercular spines. The spines number 1 and 2 gradually disappear until $21.9 \mathrm{~mm} \mathrm{SL}$ (Fig. 2F, G) and all of them disappear in adults. There are two spines on the postero-dorsal part of the opercle and two tiny spines on the temporal region, the latters originating from posttemporal bone and the formers from supracleithrum. The supraorbital crest develops during the flexion stage.

Formation of dorsal and anal fins and supporting bones

Formation of the first dorsal spine starts at $5.0 \mathrm{~mm}$ NL and is the first element to appear among all fin rays 
A

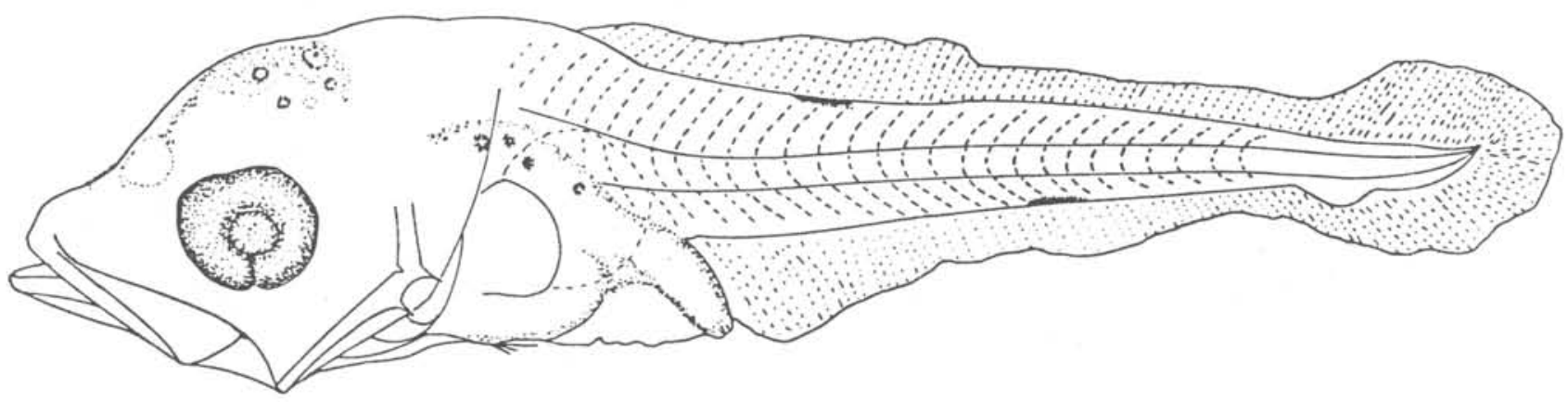

B
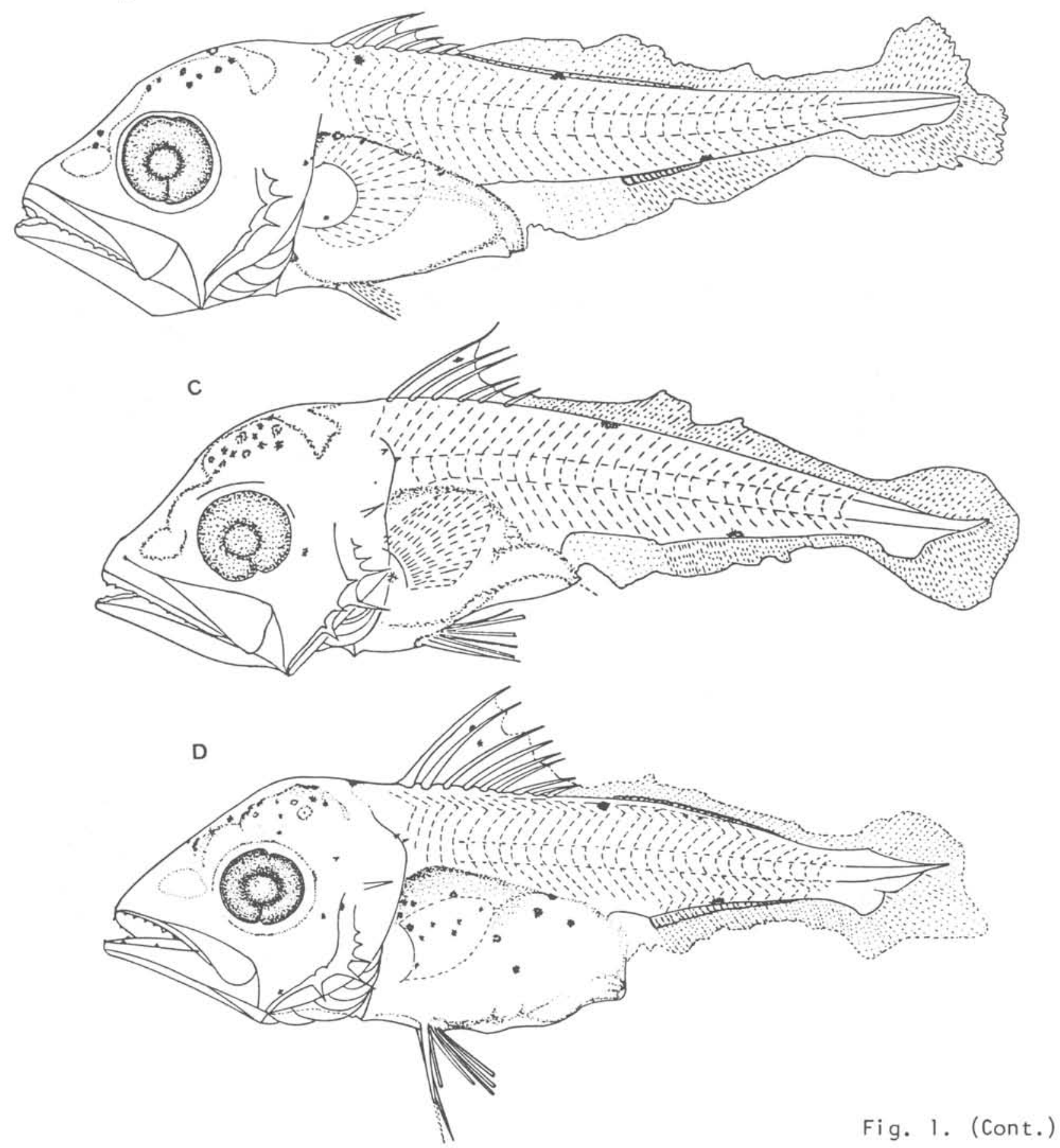


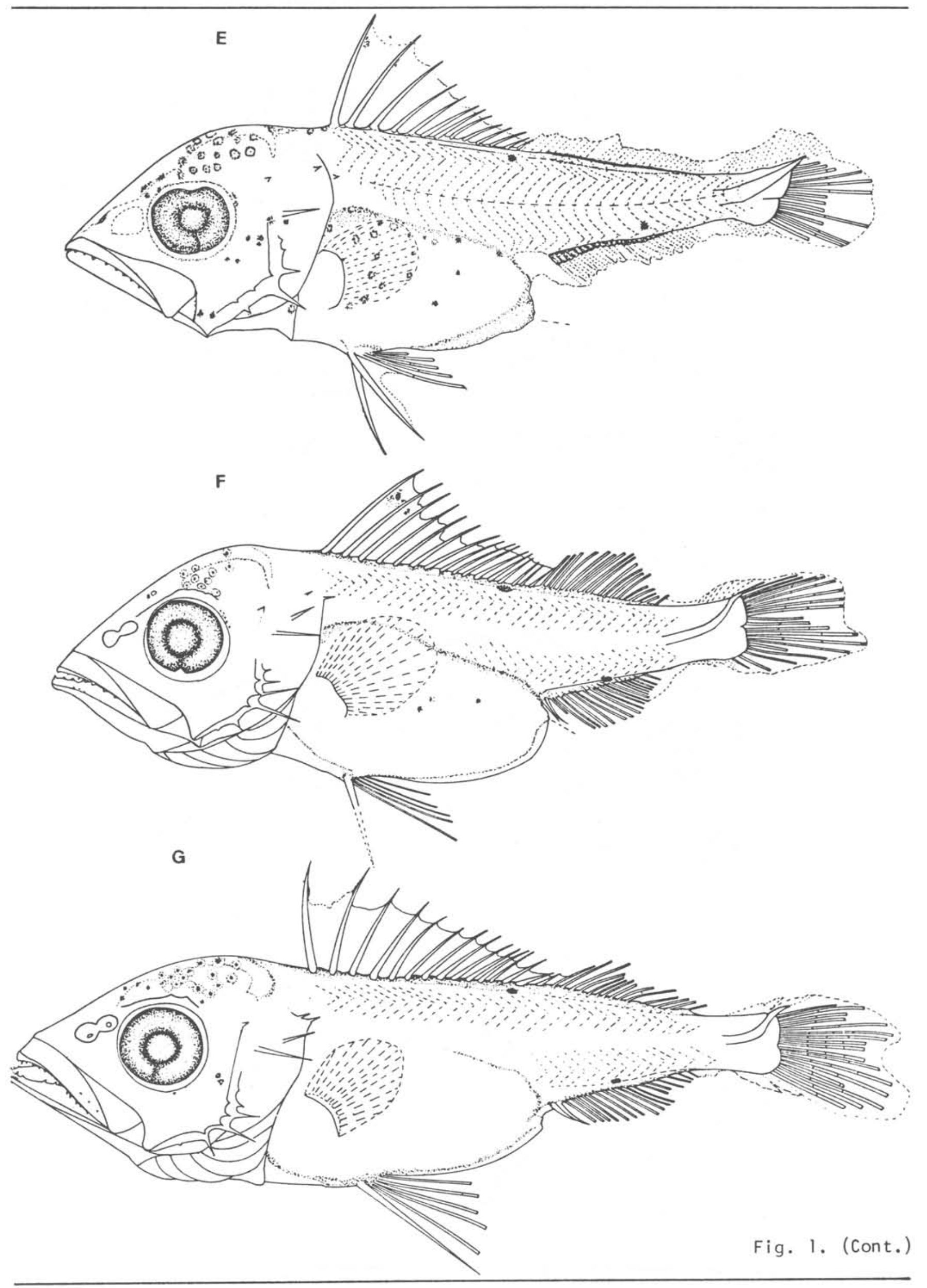



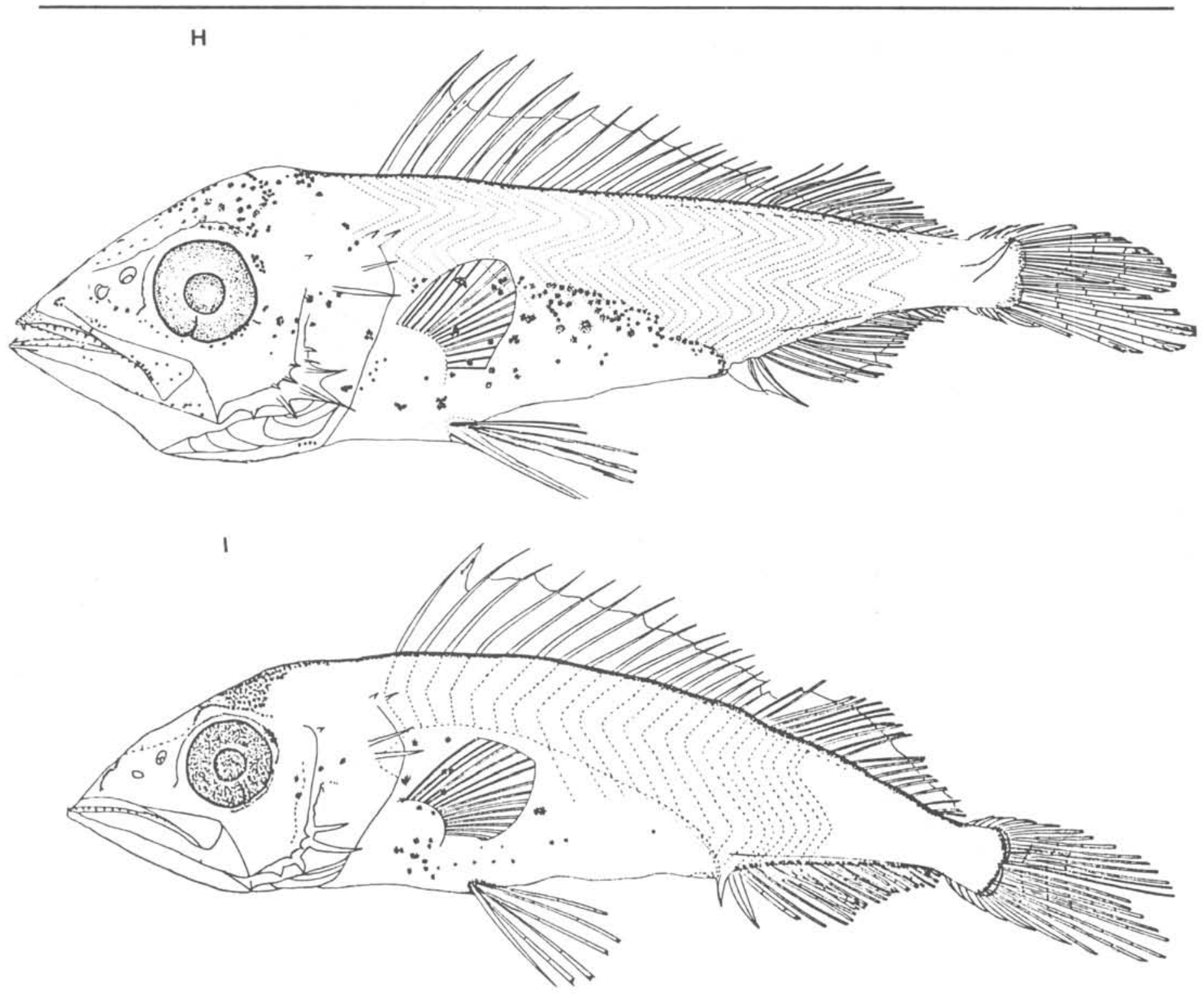

J

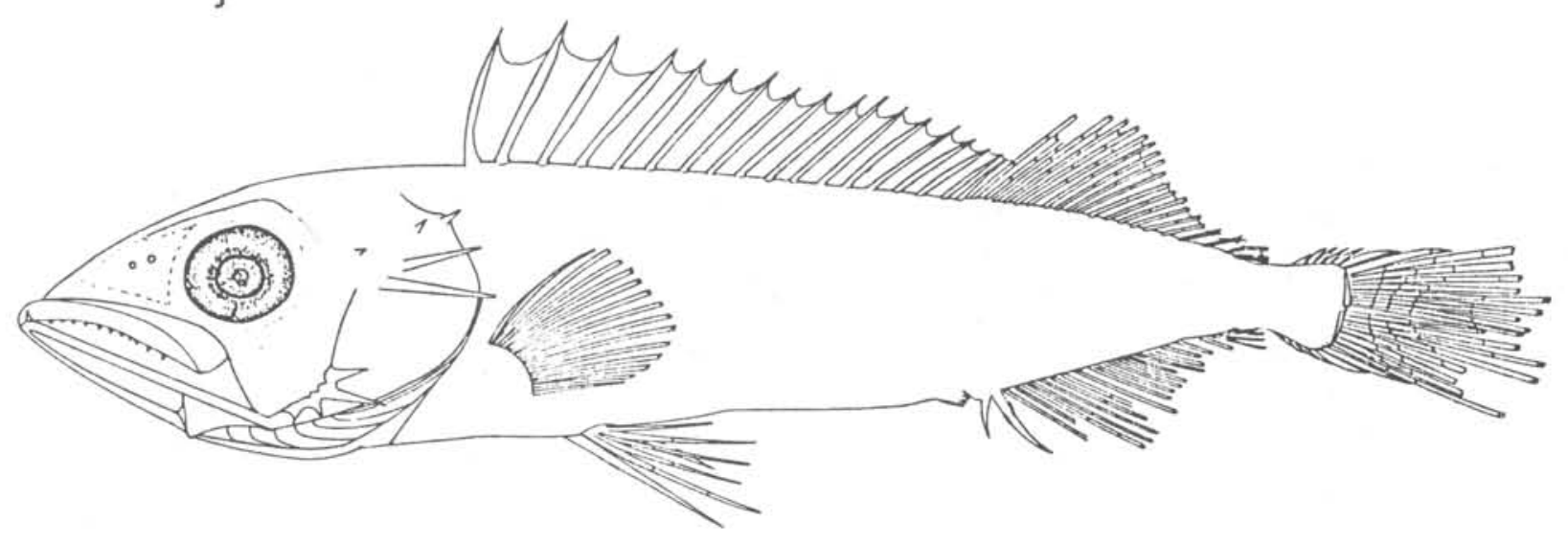

Fig. 1. Development of larvae of Thurstops lepidopoides collected from southern Brazil. A, $4.6 \mathrm{mmNL}$; B, $5.7 \mathrm{mmNL}$; C, $6.2 \mathrm{mmNL}$;, $7.5 \mathrm{mmNL}$;

E, $8.0 \mathrm{mmNL} ; \mathrm{F}, 9.8 \mathrm{mmNL} ; \mathrm{G}, 10.7 \mathrm{mmNL} ; \mathrm{H}, 13.4 \mathrm{mmSL} ; \mathrm{I}, 17.0 \mathrm{mmSL}$;

J, $22.0 \mathrm{mmSL}$. Scale bar: $1.0 \mathrm{~mm}$. 
A

B

C
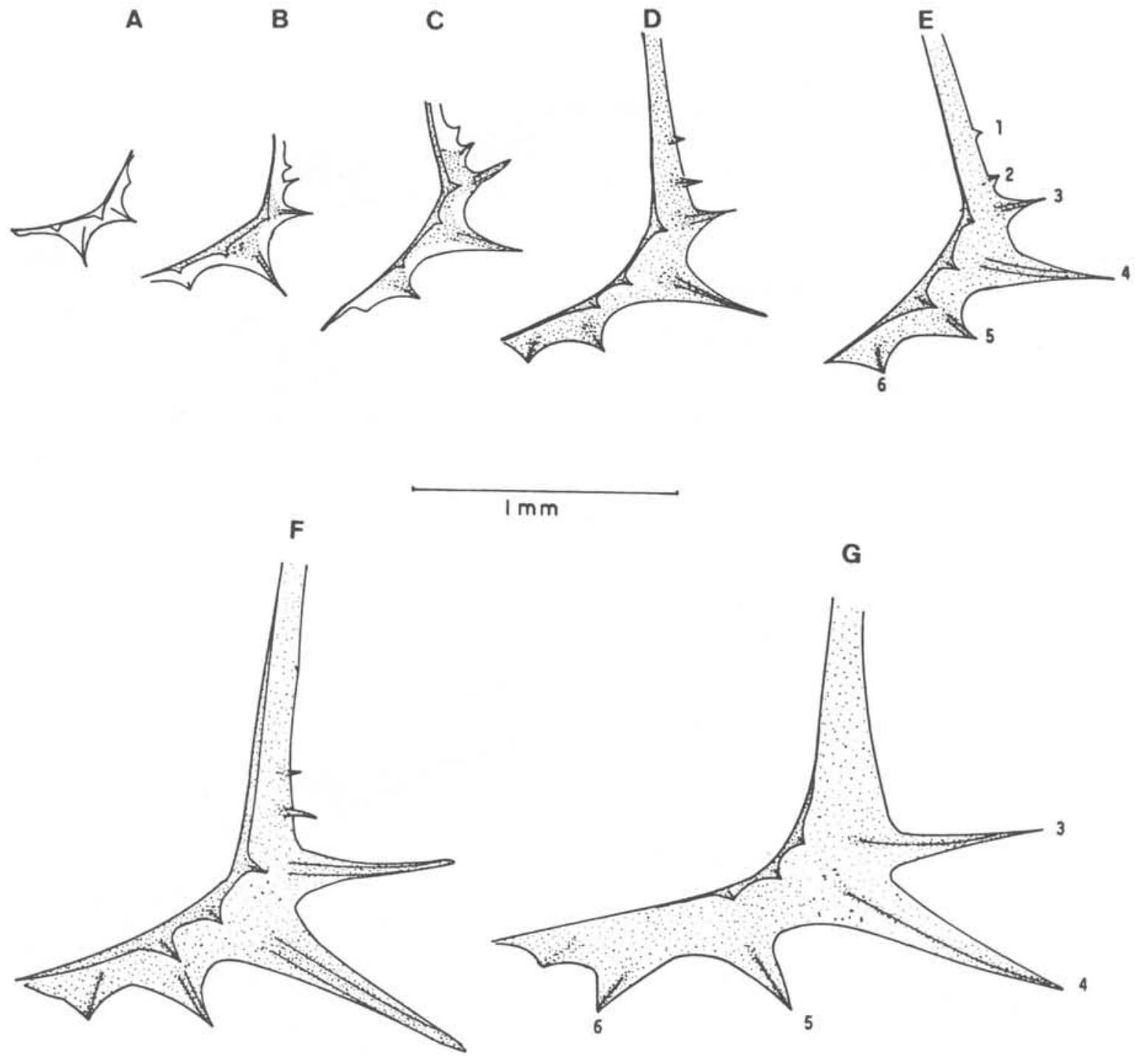

$1 \mathrm{~mm}$

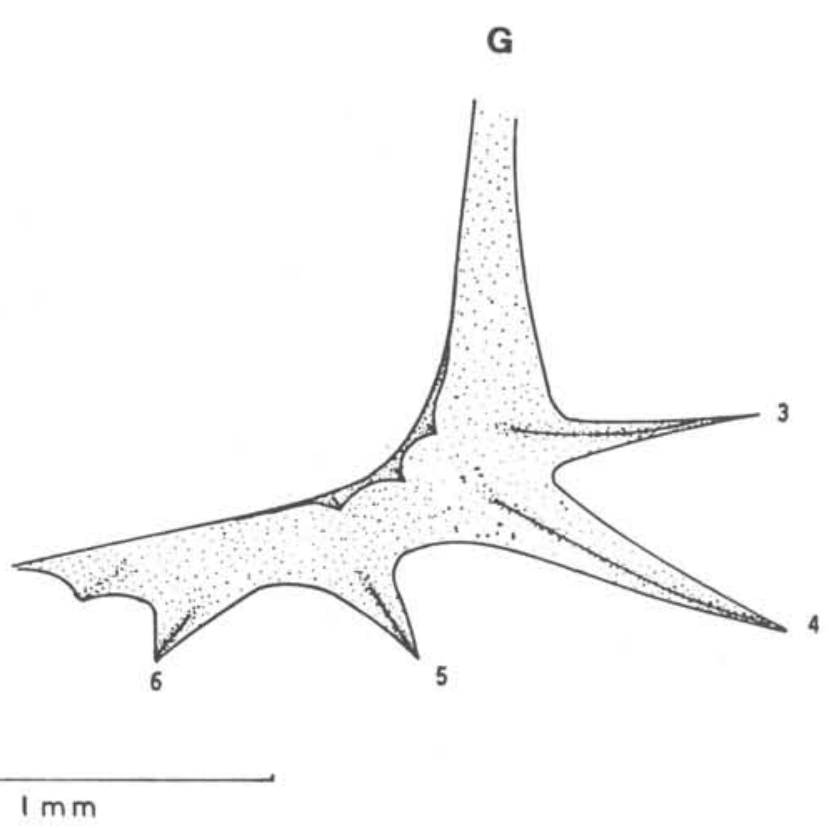

Fig. 2. Development of preopercular spines of Thyrsitops lepidopoides. A, 5.1 $\mathrm{mmNL} ; \mathrm{B}, 6.4 \mathrm{mmNL}$; C, $7.1 \mathrm{mmNL} ; \mathrm{D}, 8.3 \mathrm{mmNL}$;, $9.4 \mathrm{mmNL} ; \mathrm{F}, 13,8 \mathrm{mmNL}$; G, $21.9 \mathrm{mmSL}$.

(Table 1 and Fig. 3A). The first cartilaginous dorsal pterygiophore appears at about $7.0 \mathrm{~mm}$ NL (Fig. 3C). The $7.9 \mathrm{~mm}$ NL larva has the anterior 14 spines and 4 cartilaginous pterygiophores below the anterior dorsal spines (Fig. 3D). The $8.3 \mathrm{~mm}$ NL larva has 16 dorsal spines and 17 soft rays (Fig. 3E). The same figure shows that two anterior pterygiophores are ossified and a third one is ossifying.

The number of dorsal spines increases with growth and attains the complete number of XVII at about $10 \mathrm{~mm}$ NL, but the completion of dorsal soft rays occurs later at $12.5 \mathrm{~mm} \mathrm{SL}$. Figure $3 \mathrm{~F}$ shows well developed anterior dorsal fin elements and vertebral column of the $13.8 \mathrm{~mm}$ SL larva. The cartilaginous predorsal bone firstly appears at this size. Normally one pterygiophore inserts into each interneural space up to the 13 th neural spines, then the number of pterygiophores in each interneural space varies from the one to three without any definite pattern.

In the anal fin, some of the soft rays appear at $6.5 \mathrm{~mm} \mathrm{NL}$, then the second anal spine appears at lengths varying from 7.0 to $9.0 \mathrm{~mm} \mathrm{NL}$ (Fig. 4A, B). Larvae larger than $10.0 \mathrm{~mm} \mathrm{NL}$ already have two anal spines and completion of the 21 soft anal rays occurs at $12.5 \mathrm{~mm} \mathrm{SL}$. The anterior two 
Table 1. Fin spine and ray counts of cleared and stained larvae of. Thyrsitops lepidopoides

\begin{tabular}{|c|c|c|c|c|c|c|c|c|c|c|c|c|c|c|c|c|c|c|}
\hline \multirow{3}{*}{ Length $(\mathrm{mm})$} & \multicolumn{6}{|c|}{ Dorsal fin } & \multicolumn{6}{|c|}{ Anal fin } & \multirow{2}{*}{\multicolumn{3}{|c|}{$\frac{\text { Caudal fin }}{\text { Soft rays }}$}} & \multirow{2}{*}{\multicolumn{3}{|c|}{$\begin{array}{c}\text { Vertebral } \\
\text { number }\end{array}$}} \\
\hline & \multicolumn{3}{|c|}{ Spines } & \multicolumn{3}{|c|}{ Soft rays } & \multicolumn{3}{|c|}{ Spines } & \multicolumn{3}{|c|}{ Soft rays } & & & & & & \\
\hline & $n$ & $\bar{x}$ & S & $n$ & $\bar{x}$ & s & $n$ & $\bar{x}$ & s & $n$ & $\bar{x}$ & S & $n$ & $\bar{x}$ & S & $n$ & $\bar{x}$ & s \\
\hline $5.01-6.00$ & 08 & 5.00 & 1.07 & - & - & - & - & - & - & - & - & - & - & - & - & - & - & - \\
\hline $6.01-7.00$ & 10 & 8.50 & 2.27 & - & - & - & - & - & - & - & - & - & 01 & 16.00 & - & - & - & - \\
\hline $7.01-8.00$ & 22 & 14.14 & 1.83 & 05 & 12.20 & 4.09 & 03 & 1.33 & 0.58 & 03 & 12.00 & 3.46 & 16 & 14.19 & 2.95 & 22 & 7.68 & 5.46 \\
\hline $8.01-9.00$ & 11 & 16.00 & 1.41 & 10 & 14.70 & 2.45 & 10 & 1.10 & 0.32 & 10 & 13.60 & 3.69 & 10 & 18.10 & 0.32 & 11 & 21.00 & 1.79 \\
\hline $9.01-10.00$ & 17 & 16.82 & 0.39 & 17 & 17.18 & 1.67 & 17 & 1.94 & 0.24 & 17 & 17.18 & 1.55 & 17 & 20.24 & 1.39 & 17 & 26.12 & 1.11 \\
\hline $10.01-11.00$ & 10 & 17.00 & 0.00 & 10 & 18.60 & 1.26 & 10 & 2.00 & 0.00 & 10 & 19.00 & 1.05 & 10 & 22.20 & 0.79 & 10 & 29.50 & 1.96 \\
\hline $11.01-12.00$ & 08 & 17.00 & 0.00 & 08 & 18.25 & 1.28 & 08 & 2.00 & 0.00 & 08 & 18.38 & 1.92 & 08 & 23.00 & 1.60 & 08 & 28.63 & 4.57 \\
\hline $13.01-14.00$ & 02 & 17.00 & 0.00 & 02 & 20.00 & 0.00 & 02 & 2.00 & 0.00 & 02 & 21.00 & 0.00 & 01 & 27.00 & - & 02 & 33.00 & 0.00 \\
\hline $16.01-17.00$ & 01 & 17.00 & - & 01 & 21.00 & - & 01 & 2.00 & - & 01 & 22.00 & - & 01 & 29.00 & - & 01 & 33.00 & - \\
\hline $25.01-26.00$ & 01 & 17.00 & - & 01 & 21.00 & - & 01 & 2.00 & - & 01 & 21.00 & - & 01 & 33.00 & - & 01 & 33.00 & - \\
\hline $28.01-29.00$ & 01 & 18.00 & - & 01 & 19.00 & - & 01 & 2.00 & - & 01 & 20.00 & - & 01 & 33.00 & - & 01 & 33.00 & - \\
\hline
\end{tabular}

spines are supported by a single strong pterygiophore which inserts in front of the first haemal spine (Fig. 4C). At this size, only the first pterygiophore is fully ossified and the following six pterygiophores are ossifying. The number of pterygiophores inserting into each interhaemal space varies from two to three (Fig。4C, D).

Figure 4D shows the posterior part of the dorsal and anal fins and vertebral column of $21.9 \mathrm{~mm}$ SL specimen. At this size the posterior pterygiophores of both fins are still cartilaginous. The posterior four or five soft rays of both fins have bifurcated tips and they will later transform into finlets in adults 。 One tiny cartilaginous stay is present at the base of the last double soft ray of dorsal and anal fins.

\section{Vertebral column}

Development of the vertebral column starts with the appearance of the bud of the first cartilaginous neural arch at $6.5 \mathrm{~mm}$ NL (Fig. 3B). With growth, more neural arches are added in a posterior direction. Ossification of the vertebral column starts at about $8.0 \mathrm{~mm}$ NL anteriorly at the base of the neural arches (Fig. 3D) and proceeds quickly into posterior direction with growth. For example, in the $8.3 \mathrm{~mm}$ NL larva, 15 vertebrae are forming, of which five centra are ossified and other five are ossifying.

The first haemal arch appears on the 9 th vertebra (Fig. 3E). At $13.8 \mathrm{~mm}$ SL a11 33 vertebra are ossified and 13 ribs which articulate on the precaudal vertebrae are formed. The first rib is articulated at antero-dorsal part of the third centrum and the position of articulation gradually goes down to the ventral part of centrum up to 6 th rib (Fig. 3F). The 13th - 19th ribs are losely articulated below the parapophysis of the haemal arches. At this size two epineural spines appear on the first and second neural spines and two

intermuscular spines appear on the third and fourth centra. With exception of the first centrum, all centra have neural prezygapophysis and postzygapophysis. The ninth to the 30 th centra have haemal prezygapophysis and postzygapophysis. Formation of the vertebral column is shown in Figure 5. All larvae larger than $12.0 \mathrm{~mm}$ NL have total 33 vertebrae of which 17 are precaudal and 16 are cauda1. 
A
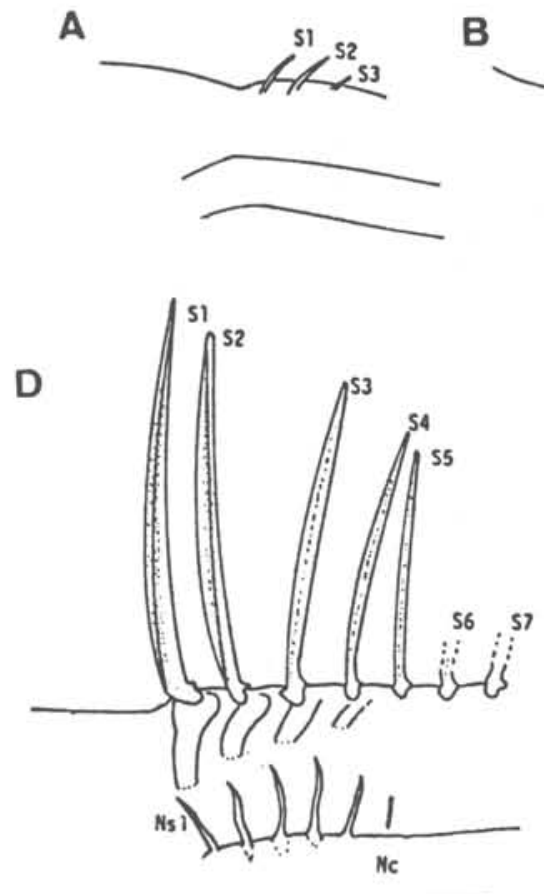

$\longdiv { \mathrm { tmm } }$
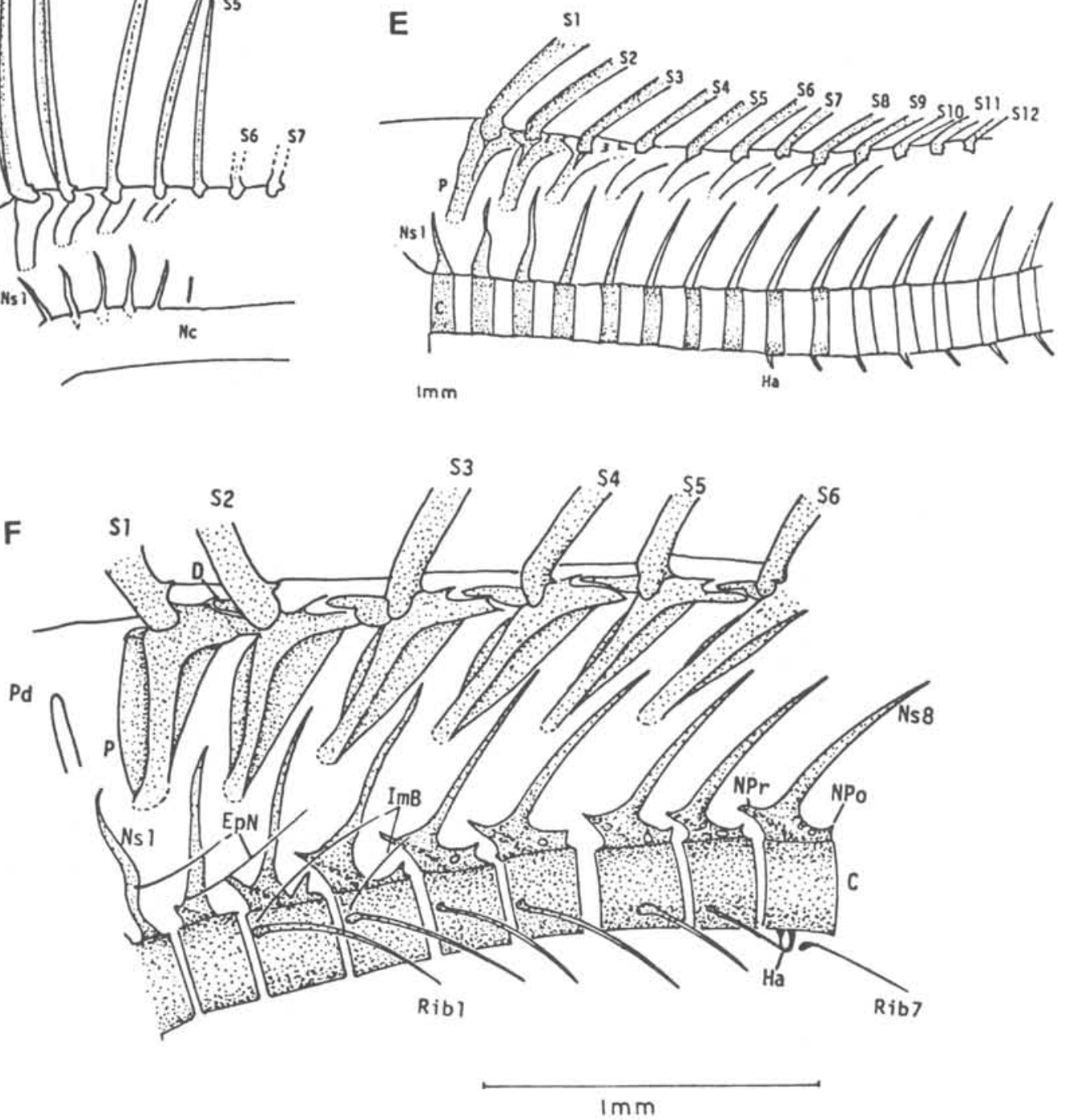

Fig. 3. Development of spinous dorsal fins and supporting bones and anterior part of the vertebral column in $T$. lepidopoides larvae. Scale bar: $1.0 \mathrm{~mm}$. A, $5.1 \mathrm{mmNL}$; B, $6.4 \mathrm{mmNL}$; C, $7.1 \mathrm{mmNL}$; D, $7.9 \mathrm{mmNL}$; $E, 8.3$ mmNL; F, $13.7 \mathrm{mmSL}$. Ce, centrum; Dr, distal radial; EpN, epineural; $\mathrm{Ha}$, haemal spine; ImB, intermuscular bone; NPo, neural postzygaphosis; $\mathrm{NPr}$, neural prezygapohysis; $\mathrm{Ns}_{1}$, lst. neural spine; P, pterygiophore; $\mathrm{Pd}$, predorsal bone; $\mathrm{Rib}_{1}$, 1st. $\mathrm{rib} ; \mathrm{S}_{1}$, 1st. spiny ray in the dorsal fin. 
A
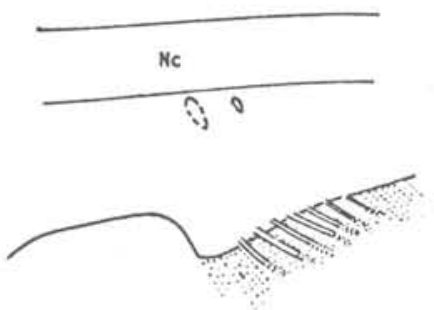

C
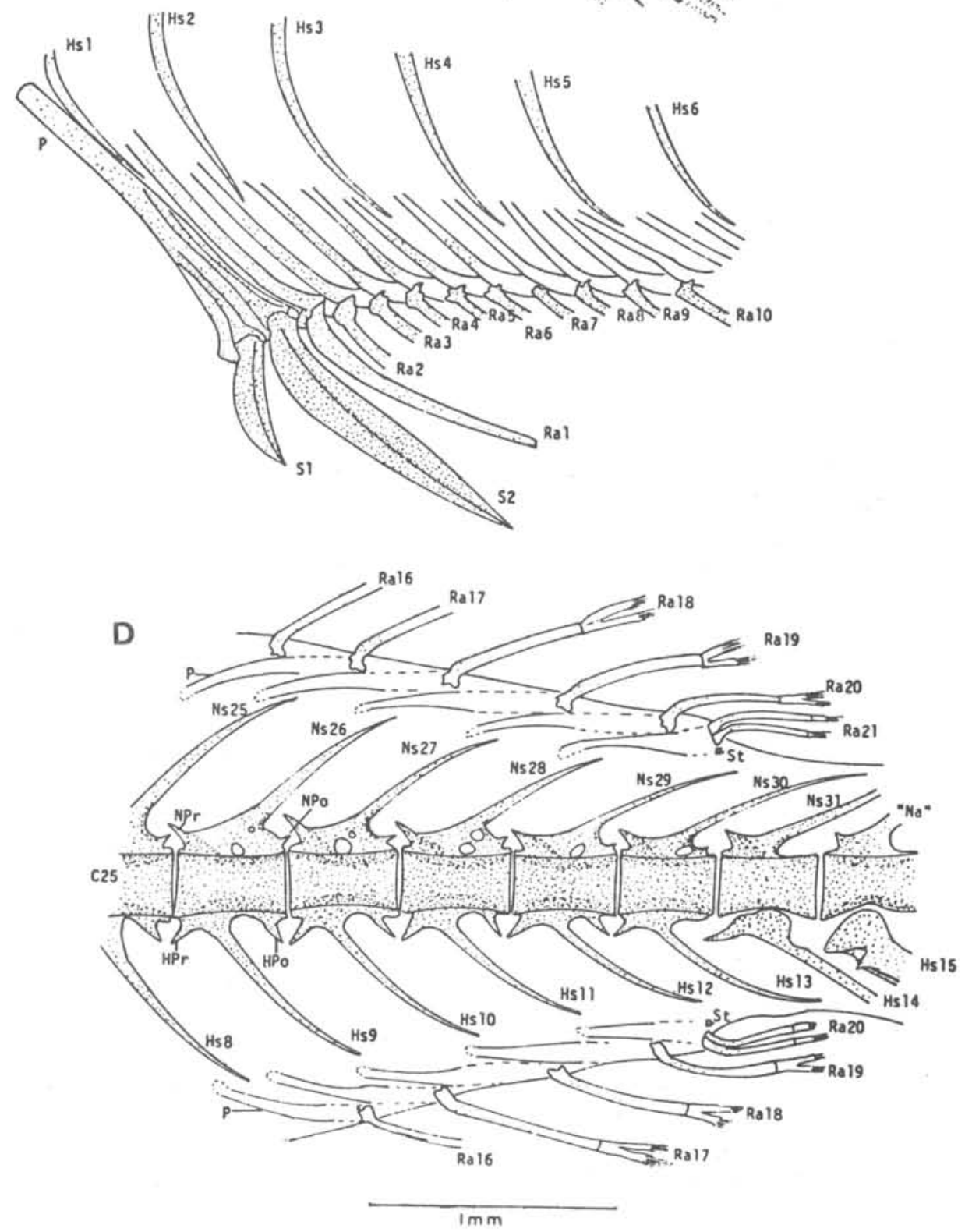

Fig. 4. A, B and C show development of the anterior part of the anal fin and supporting bones and $D$ shows the posterior part of the anal and dorsal $\mathrm{fin}$ and a part of the vertebral column. A, $7.9 \mathrm{mmNL}$; B, $8.3 \mathrm{mmNL} ; \mathrm{C}, 21.9 \mathrm{mmSL} ; \mathrm{D}, 21.9 \mathrm{mmSL}$. Hs 1 , 1st. haemal spine; "Na", specialized neural arch; NPo, neural postzygapophysis; NPr, neural prezygapophysis; $\mathrm{Nc}$, notochord; $\mathrm{Ns}_{25}, 25$ th neural spine; $P$, pterygiophore; $R_{1}$, lst. anal (or dorsal) fin ray; $S_{1}$, lst. anal spine; St, stay. 


\section{- Precoudal vertebrae \\ - Caudal vertebrae}

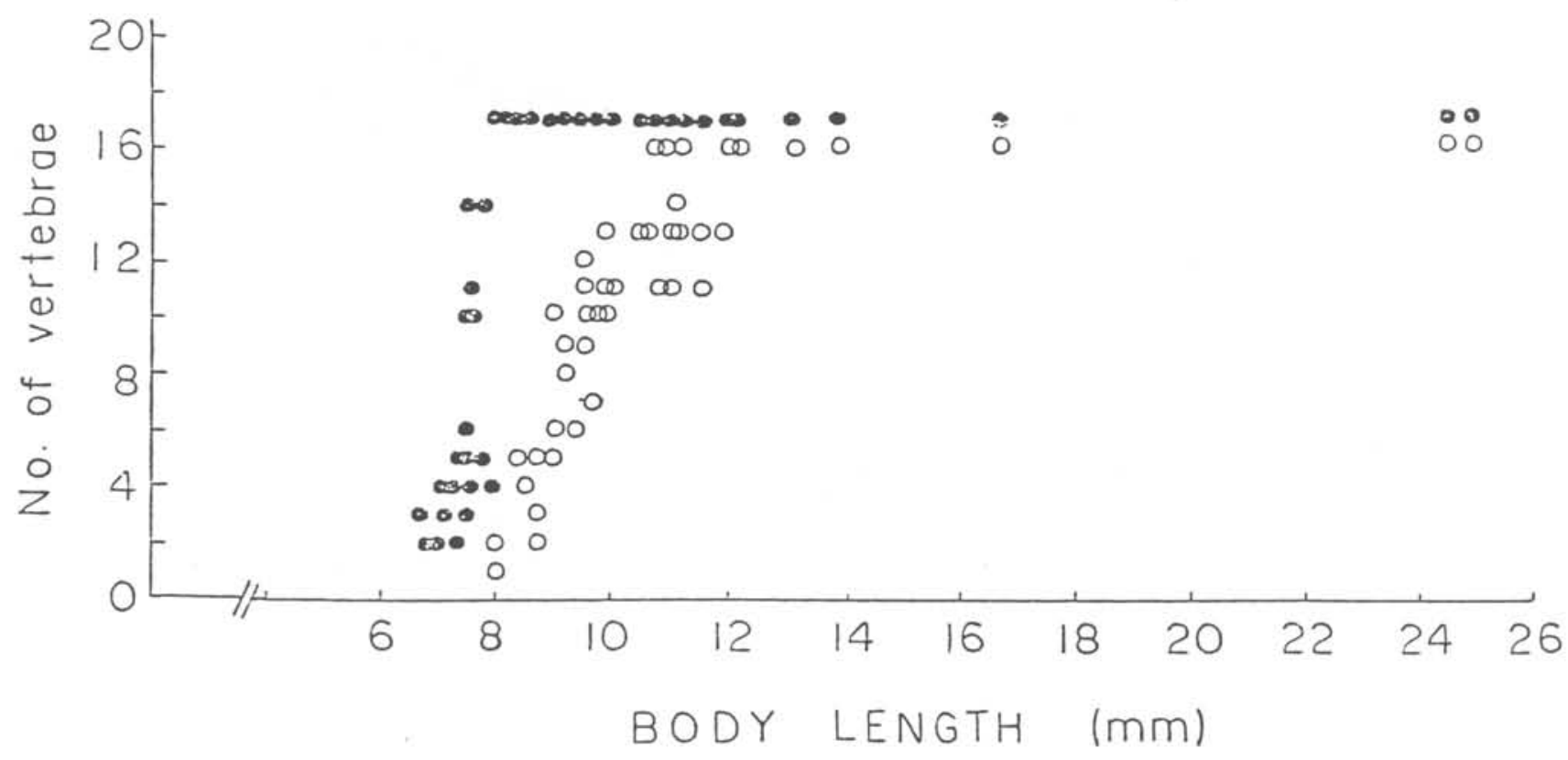

Fig. 5. Diagram of number of vertebrae in Thyrsitops lepidopoides larvae between 6 and $26 \mathrm{~mm}$ length.

\section{Pectoral girdle and suspensorium}

The cleithrum is one of the first structures to appear as a thin sliver behind the head at $2.9 \mathrm{~mm} \mathrm{NL}$. At $5.0 \mathrm{~mm}$ NL the posttemporal, supracleithrum and origin of the cartilaginous coracoscapular are visible (Fig. 6A). The cleithrum is only one bone, but due to a twist at the middle portion, it seems to be comprised of two bones (Fig. 6A, B, c).

Uptake of alizarin red of the pectoral girdle starts from the central portion of the cleithrum at about $6.5 \mathrm{~mm}$ NL. At this size, several pectoral rays are formed and two postcleithra appear behind the cleithrum (Fig. 6B). The posttemporal which is articulated on the supracleithrum posteriorly, has a tiny spine and the supracleithrum also has a spine on its posterior median edge. These two spines are exposed out of the skin and are visible in the temporal region (Fig. 1C).

At $8.3 \mathrm{~mm} \mathrm{NL} \mathrm{(Fig.} \mathrm{6C),} \mathrm{al1}$ components of the suspensorium (posttemporal, supracleithrum and postcleithra) are formed and ossified.
Two postcleithra are connected to each other and on the doral side of the dorsal postcleithrum, a small process appears, which becomes disk-1ike in juvenile and adult specimens (Fig. 6D, $E, F)$. The number of pectoral fin rays in the $8.3 \mathrm{~mm}$ NL larva is 13 and origins of 3 radials are visible.

Formation of pectoral fin rays starts from the doral part and proceeds ventrad. At $12.0 \mathrm{~mm}$ NL all 15 rays and the coracoscapular cartilage are formed. In the largest specimen examined the second tiny spine on the posterior part of the posttemporal appeared (Fig. 6E), however these spines at larval and juvenile stages in the temporal region disappear in the adult stage (Fig. 6F).

\section{Caudal complex}

Development of the caudal fin starts at about $6.5 \mathrm{~mm} \mathrm{NL}$. Before notochord flexion five caudal rays and cartilaginous buds of hypurals and the parhypural are forming on the ventral side of notochord. When the notochord starts to flex at $7.0 \mathrm{~mm} \mathrm{NL}$, ten caudal rays, four cartilaginous hypurals and 

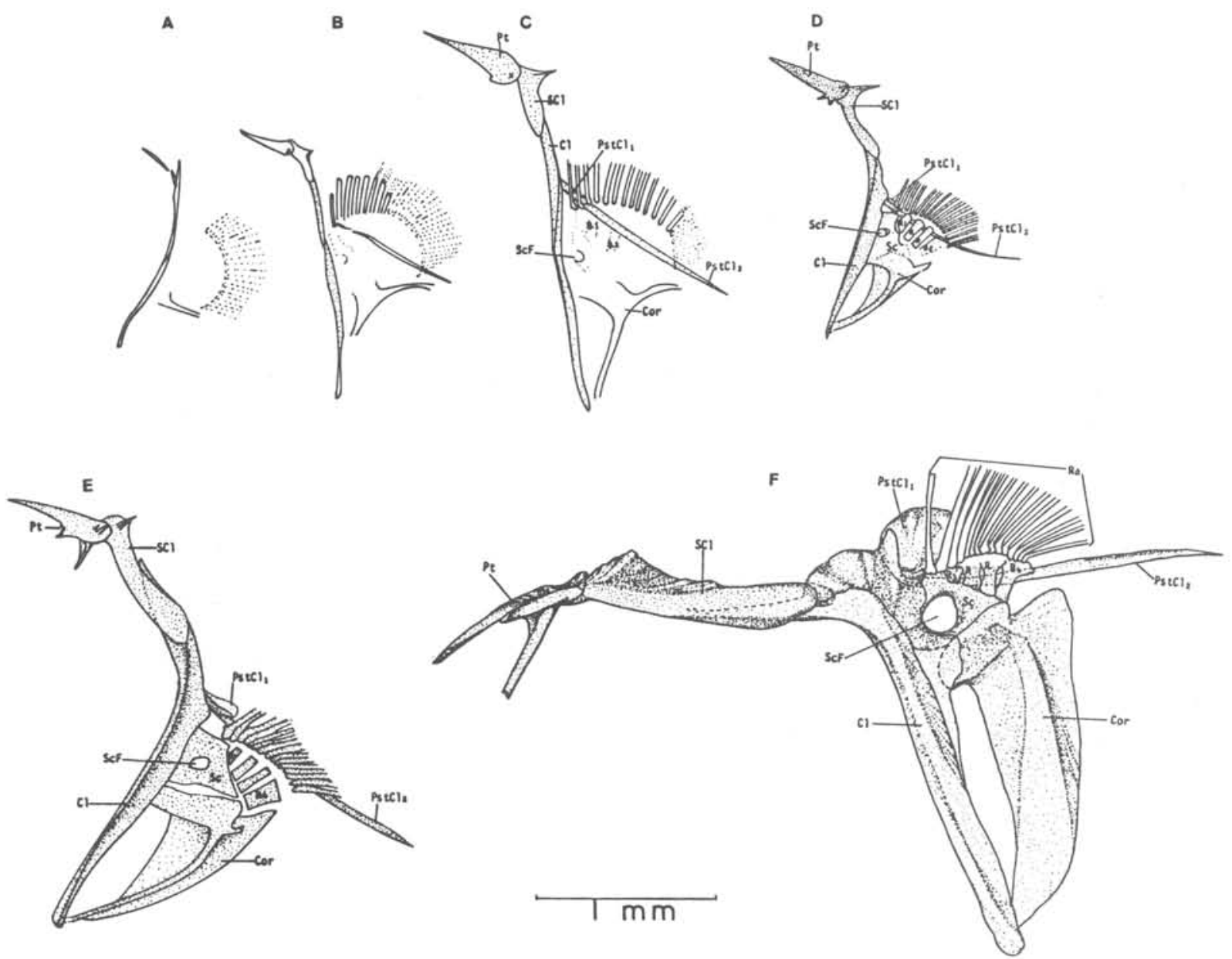

Fig. 6. Left lateral view of the pectoral girdle in $T$. lepidopoides showing ontogeny. A, $5.3 \mathrm{mmNL}$; B, $7.1 \mathrm{mmNL}$; $C, 8.3 \mathrm{mmNL} ; \mathrm{D}, 13.7$ $\mathrm{mmSL} ; \mathrm{E}, 27.5 \mathrm{mmSL}$. F, $242.0 \mathrm{mmSL}$ (adult). C1, cleithrum; Cor, coracoid; PstCl, postcleithrum; $R_{1}$, radial 1; Sc, scapular; ScF, scapular foramem; SCl, supracleithrum; Pt, posttemporal.

parhypural are developed (Fig. 7B). Uptake of alizarin red starts at the bases of caudal fin rays at about $8.0 \mathrm{~mm}$. NL. The cartilaginous haemal spine are visible on the preural centra 2 and 3 , preceding the parhypural. When the notochord is almost flexed, the principal caudal rays $(9+8)$ are formed and the urostyle starts to ossify. Following this stage, ossification extends to the preural centrum 2, the hypurals and the parhypural. Cartilaginous neural spines and the specialized neural arch also start to appear (Fig. 7E).

At $13.8 \mathrm{~mm}$ SL ossification proceeds to the last haemal spine and preural centra 3 and 4 . The larger anterior uroneural appears above the urostyle at this stage. At $21.9 \mathrm{~mm} \mathrm{SL}$, most components of the caudal complex are ossified, except the three epurals (Fig. 7G). Other structures which appear at this stage are: the smaller posterior uroneural, the parhypurapophysis at the base of the parhypural and the well-developed specialized neural arch. Al1 five hypurals are still separated. At $27.5 \mathrm{~mm}$ SL (Fig. $7 \mathrm{H}$ ), the first and the second hypurals are fused and three epurals are ossified. We could not find any radial cartilage as found in Pagrus major larvae (Matsuoka, 1982), nor procurrent spur of Johnson (1975).

In adults, hypurals are reduced to three due to a fusion (Fig. 7I). The 

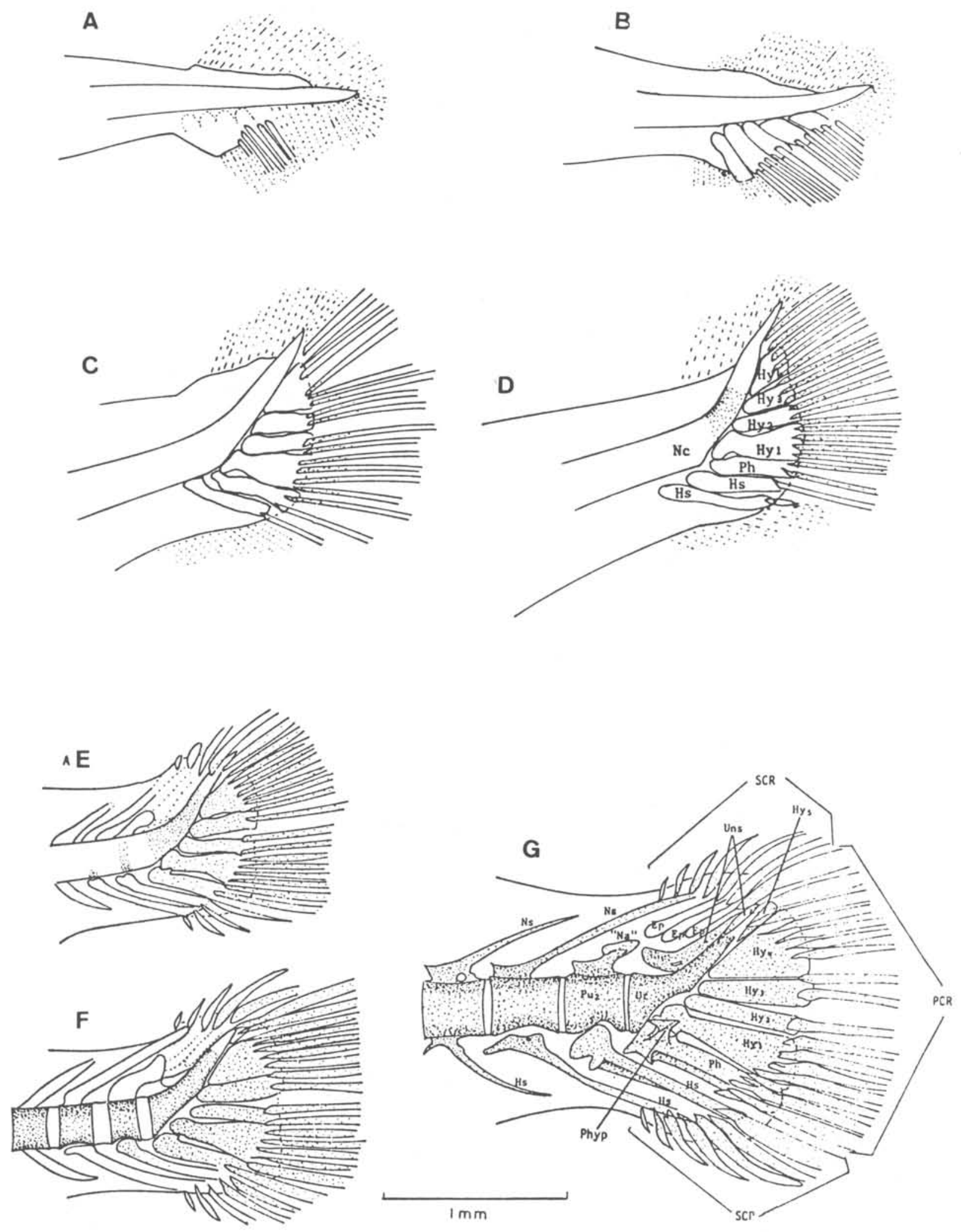

Fig. 7. (Cont.) 

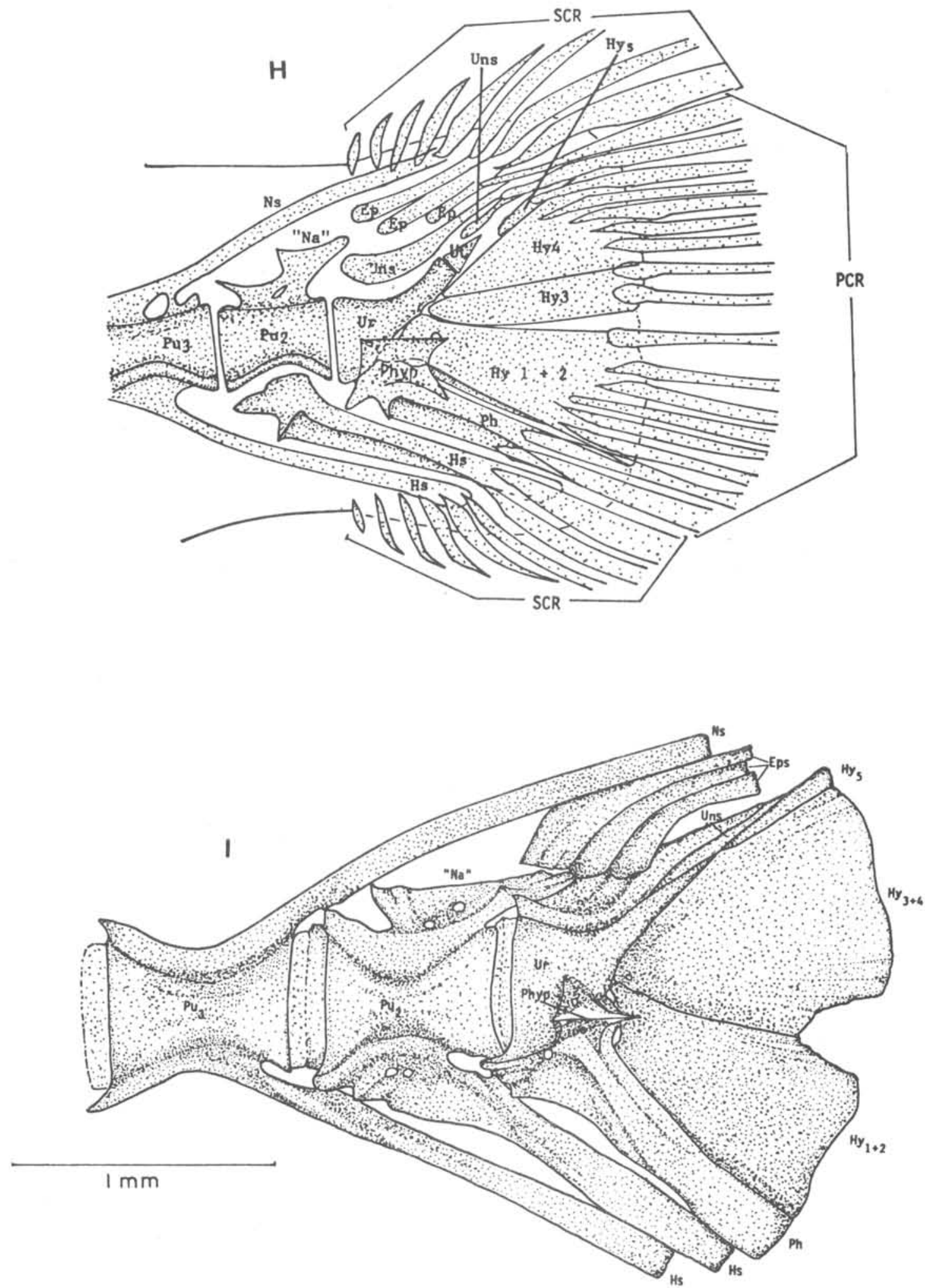

Fig. 7. Development of the caudal complex in Thyrsitops lepidopoides larvae. A, $6.4 \mathrm{mmNL} ; \mathrm{B}, 7.1 \mathrm{~mm} \mathrm{NL}$; C, $8.3 \mathrm{mmNL}$; D, $9.4 \mathrm{mmNL}$; E, $11.4 \mathrm{mmNL}$; F, $13.7 \mathrm{mmSL} ; \mathrm{G}, 21.9 \mathrm{mmSL} ; \mathrm{H}, 27.5 \mathrm{mmSL} ; 1,242.0 \mathrm{mmSL}$ (adult). Ep, epural; Hy, hypural; Hs, haemal spine; "Na" specialized neural arch; Nc, notochord; Ns, neural spine; Ph, parhypural; PCR, principal caudal rays; Phyp, parhypurapophysis; $\mathrm{Pu}_{2}$, preural centrum 2; Uns, uroneurals; Ur, urostyle; SCR, secondary caudal rays. 
Bolm Inst. oceanogr., S Paulo, 34 (ünico): 1986

$9+8$ principal and 16 secondary caudal rays are supported by elements of the urostyle and preural centra 2 and 3 .

\section{Discussion}

The larvae were identified as belonging to the family Gempylidae based on the following characters: well-developed dorsal and ventral spines, the preopercular spination and general body shape (Voss, 1954). Identification of $T$. lepidopoides larvae was made on specimens larger than $11.0 \mathrm{~mm}$, since at this size all meristic characters are already formed. After identifying the larger specimens, we followed a sequencial developmental series down to $2.5 \mathrm{~mm}$ NL. The larvae smaller than $6.0 \mathrm{~mm}$ NL can be confused with those of scombrid larvae (e.g. Thunnus, Euthynnus, Katsuwonus, Auxis), but we can distinguish them by myomere count. The Scombrolabrax heterolepis Iarvae have similar myomere count $(=30)$ and body form, but the $T$. lepidopoides larvae develop dorsal and ventral fin spines since early stage and they have conspicuous pigments on the bases of dorsal and anal fins during preflexion and flexion stages.

After analysing a large series of gempylid larvae, Voss (1954) concluded that the spinous structure of the preopercular margin is one of the most important larval characters for species identification. From known gempylid larvae, six species have serrated preopercular spine or spines (Lepidocybium, Neoepinnula, Epinnula, Rexea, Nealotus and Diplospinus) and five have no serrated spines (Thyrsitops, Thyrsites, Promethichthys, Nesiarchus and Gempylus) (Co1lette et al., 1984). The number of preopercular spines of gempylid larvae ranges from one to six and only Thyrsitops has six preopercular spines during larval stage. However, the upper two short spines disappear during the juvenile stage.

\section{Acknowledgements}

The authors wish to thank Dr. William J. Richards and Dr. Thomas Potthoff of the National Marine Fisheries Service, for revisions and critical reading of the manuscript. The financial support of this work came from the Financiadora de
Estudos e Projetos (FINEP). The junior author received the research

fellow ship of the Conselho Nacional de Desenvolvimento Científico e Tecnológico (CNPq). This is a contribution no 617 of the Instituto Oceanográfico da Universidade de São Paulo.

\section{References}

COLLETTE, B。B.; POTTHOFF, T.; RICHARDS, W. J.; UEYANAGI, S.; RUSSO, J. L. \& NISHIKAWA, Y. 1984. Scombroidei: development and relationships. In: Moser, H. G., ed.-in-chief Ontogeny and sistematics of fishes. Based on an International Symposium Dedicated to the Memory of Elbert Halvor Ah1strom. The Symposium was held August 15-18, 1983, La Jolla, Calif. New York, American Society of Ichthyologist and Herpetologists, p. 511-620.

DINGERKUS, G. \& UHLER, L. D. 1977. Enzyme clearing of alcian blue stained whole small vertebrates for demonstration of cartilage. Stain Techno1., 52(4):229-232.

FRITZSCHE, R. A. \& JOHNSON, G. D. 1980. Early osteological development of white perch and striped bass with emphasis on identification of their larvae. Trans. Am. Fish. Soc., 109: 397-406。

GORBUNOVA, N. N. 1977. Larvae and juveniles of some species of trichiuroid fishes (Trichiuroidae: Gempylidae and Trichiuridae). Trudy Inst. Okeano1. Akad. Nauk, 109:133148. (In Russian).

\section{Larvae of} trichiroid fishes from collection of the International Mexican Biological Center (Gempylidae, Trichiuridae, Pisces). Trudy Inst. Okeanol. Akad. Nauk, 118:85-106. (In Russian).

JAGER, B. V. D. 1955. The South African pilchard (Sardinops ocellata). The development of the snoek (Thyrsites atun) a fish predator of the pilchard. Invst 1 Rep. Div. Fish. Un. S. Afr., (19):1-16. 
JOHNSON, G.D. 1975. The procurrent spur: an undescribed perciform caudal character and its phylogenetic implications. Occ. Pap. Calif. Acad. Sci., (121):1-23.

JONES, S. 1960. On the snake mackere1, Gempylus serpens Cuvier from the Laccadive Sea. J. mar. biol. Ass. India, 2(1):85-88.

MATSUOKA, M. 1982. Development of vertebral column and caudal skeleton of the red seabream Pagrus major. Jap. J. Ichthyo1., 29(3):285-294. (In Japanese).

MOSER, H. G. \& AHLSTROM, E. H. 1970. Development of lantern fishes of family Myctophidae in the California Current. Bul1. Los Ang. Cty Mus. nat. Hist., (7): 1-145.

NAKAMURA, I. \& PAXTON, J. R. 1977. A juvenile gempylid fish, Nealotus tripes, from eastern Australia. Aust. Zoo1., 19(2):179-184.

NISHIKAWA, Y. 1982. Early development of the fishes of the family Gempylidae. I. Larvae and juveniles of escolar Lepidocybium flavobrunneum (Smith). Bul1. far Sea Fish. Res. Lab., (19): $1-14$.

NISHIKAWA, Y. 1984a. Postlarvae and juveniles of Thyrsitops lepidopoides Cuvier (Pisces: Gempylidae). Bull. far Seas Fish. Res. Lab., (21):9-17.

1984b. Postlarval

development of the gempylid fish Paradiplospinus gracilis (Brauer). Bu11. far Seas Fish. Res. Lab., (21): $1-8$.
NISHIKAWA, Y. 1984C. Additional description of larvae of Neoepinnula orientalis (Gilchrist and Von Bonde) (Pisces: Gempylidae). Bull. far Seas Fish. Res. Lab., (21):19-24.

\& NAKAMURA, I. 1978. Postlarvae and juveniles of the gempylid fish, Neoepinnula orientalis (Gilchrist and Von Bonde), from the north Arabian Sea. Bull. far seas Fishs. Res. Lab., (16):75-91.

POTTHOFF, T.; RICHARDS, W. J. \& UEYANAGI, S. 1980. Development of Scombrolabrax heterolepis (Pisces, Scombrolabracidae) and comments on familial relationships. Bull. mar. Sci., 30(2):329-357.

STRASBURG, D. W. 1964. Postlarval scombrid fishes of the genera Acanthocybium, Nealotus, and Diplospinus from central Pacific Ocean. Pacif. Sci., 18(2):174-185.

VosS, N. A. 1954. The postlarva1 development of the fishes of the family Gempylidae from the Florida Current. I. Nesiarchus Johnson and Gempylus Cuv, and Val. Bull. mar. Sci. Gulf Caribb., 4(2):120159.

YEVSEYENKO, S. A. \& SEREBRYAKOV, V. P. 1974. Larvae of Diplospinus multistriatus Maul (Pisces, Gempylidae) from the northwestern Atlantic. J. Ichthyol., 14(1): 92-98.
(Received 28-Sept-1986; accepted 18-Dec-1986) 